\title{
MEROPS APIASTER.
}

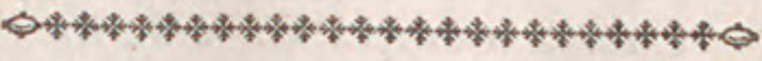

\section{CHARACTER GENERICUS,}

Roftrum curvatum, compreffum, carinatum.

Lingua apice laciniata,

Pedes grefforii.

Lin. Syf. Nat. p. 18 z.

CHARACTER SPECIFICUS, Ec.

MEROPS dorfo ferrugineo, abdomine caudaque viridi-cærulefcente, rectricibus duabus longioribus, gula lutea.

$$
\text { Lin. Syf. Nat. p. } 182 .
$$

MEROPS.

Bell. av. 16.

Gejn. av. 599 .

Aldr. 1. p. 871 .

APIASTER.

Briff. av. 4. p. 532 . n. 1.

Formofam hanc avem, quam ignorat Britannia, alunt calidioris Europæ variæ regiones; Græcia nec non infulæ quæ in Egæo mari abundanter,

Creta 
Creta autem precipue, in qua exerceri dicitur lepida ifta et aeria avium quafi pif́catio, cujus meminit Bellonius. Cicada nempe vel aciculæ incurvatæ vel hamo pifcatorio affixa e filo longiffimo in altum projcitur, in quam celerrime volantem Merops, infectis fedulo invigilans, fimul atque adfpexerit fubito impetu involat, et efca avide devorata, cedit ipfe in prædam pueris Cretenfibus. Nidum e mufco confectum ponit Merops Apiafter in ripis fluviorum. 



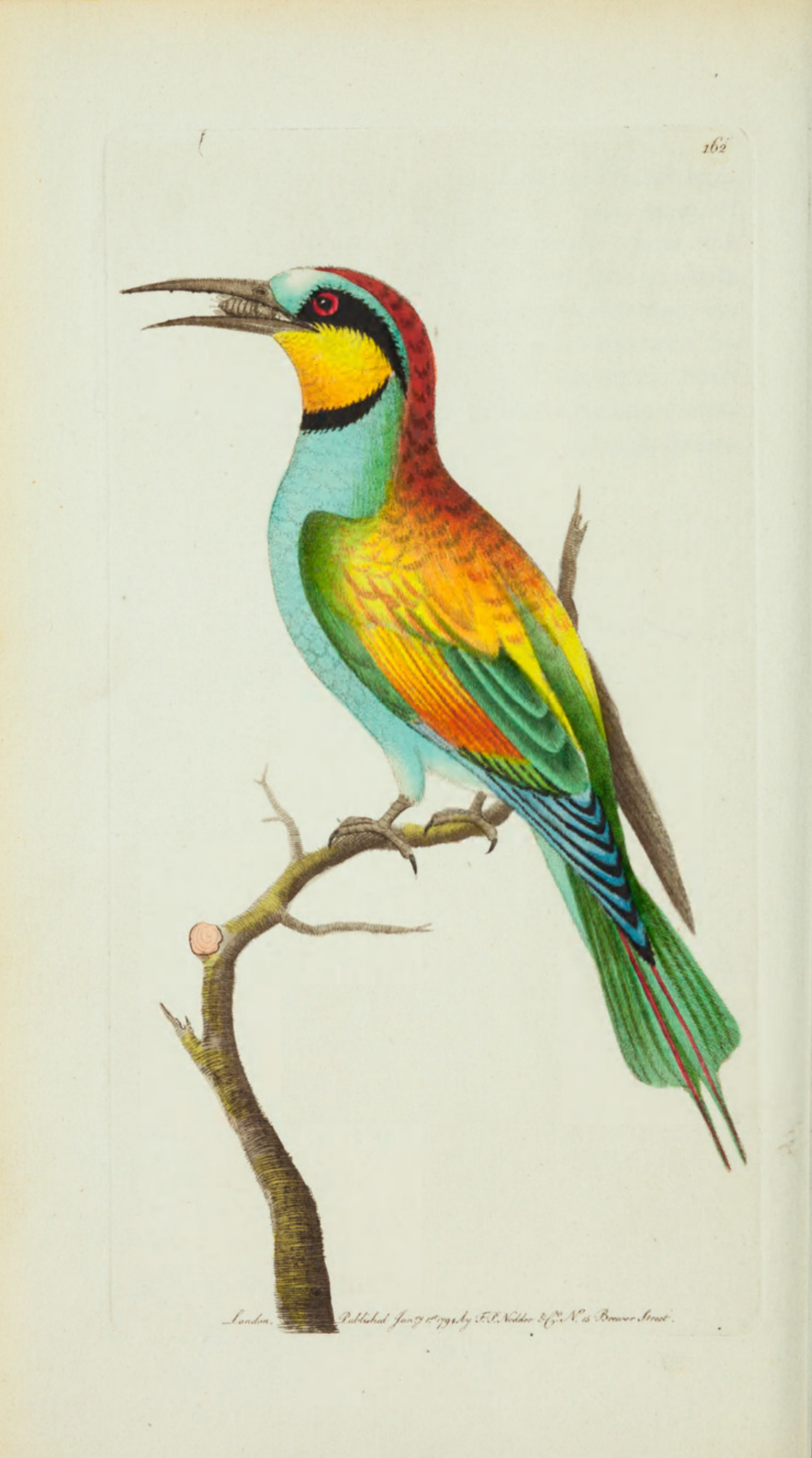


THE

\section{EUROPEAN BEE-EATER.}

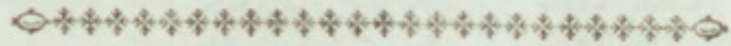

GENERIC CHARACTER.

Bill curved, compreffed, carinated, and fharppointed.

Tongue (generally) laciniated at the tip.

Feet grefforial, i. e. three toes forward and one backward; and the three lower joints of the middle toe clofely joined to thofe of the outmoft.

\section{SPECIFIC CHARACTER, EंC.}

BEE-EATER with the back ferruginous, the abdomen and tail blue-green, the two middle tail-feathers longer than the reft, the throat yellow.

THE COMMON BEE-EATER OR MEROPS. The BEE-EATER.

$$
\text { Will. p. } 147 \text {. }
$$

LE GUÉPIER.

$$
\begin{aligned}
& \text { Buf. 6. p. } 480 . \text { t. } 23 \text {. } \\
& \text { Pl. enl. } 938 .
\end{aligned}
$$

This beautiful bird is a native of many of the warmer parts of Europe, but is never feen in the I 2 Britifh 
Britifh dominions. It is extremely common in Greece and the iflands of the Archipelago; and in Crete is more peculiarly plentiful. It is in this latter ifland that the curious mode of bird-catching defcribed by Bellonius is faid to be frequently practifed with fuccefs, viz. a cicada is faftened on a bent pin, or a filh-hook, and tied to a long line. The infect when thrown from the hand, afcends into the air, and flies with rapidity; the Merops, ever on the watch for infects, feeing the cicada, fprings at it, and fwallowing the bait, is thus taken by the Cretan boys. The Bee-Eater builds in the banks of rivers, and forms its neft of mofs, 


\section{$2 \mathrm{BHL}$ Biodiversity Heritage Library}

Shaw, George. 1793. "The European Bee-Eater, Merops apiaster [PI. 162]." The Naturalist's Miscellany 5(LIII), https://doi.org/10.5962/p.310741.

View This Item Online: https://www.biodiversitylibrary.org/item/276340

DOI: https://doi.org/10.5962/p.310741

Permalink: https://www.biodiversitylibrary.org/partpdf/310741

\section{Holding Institution}

Museums Victoria

\section{Sponsored by}

Atlas of Living Australia

\section{Copyright \& Reuse}

Copyright Status: Public domain. The BHL considers that this work is no longer under copyright protection.

This document was created from content at the Biodiversity Heritage Library, the world's largest open access digital library for biodiversity literature and archives. Visit BHL at https://www.biodiversitylibrary.org. 